\title{
Temporal variability of soil chemical properties under conventional and silvopastoral cultivation systems
}

\author{
Variação temporal dos atributos químicos do solo em sistemas de cultivo convencional e \\ silvipastoril \\ Variación temporal de los atributos químicos del suelo em el sistema de cultivo convencional y \\ silvopastoril
}

Antonio Clementino dos Santos ORCID: https://orcid.org/0000-0001-7943-7923 Federal University of Northern Tocantins, Brazil E-mail: antclementino@yahoo.com

Márcio Odilon Dias Rodrigues ORCID: https://orcid.org/0000-0002-9516-0095 Federal University of Northern Tocantins, Brazil E-mail: marciozoouft@hotmail.com

José Geraldo Donizetti dos Santos ORCID: https://orcid.org/0000-0001-5818-9158 Federal University of Northern Tocantins, Brazil E-mail: jgsanttos@mail.uft.edu.br

Elcivan Bento da Nóbrega ORCID: https://orcid.org/0000-0003-4831-5768 Federal University of Northern Tocantins, Brazil E-mail: enobrega@uft.edu.br

Rubson da Costa Leite ORCID: https://orcid.org/0000-0002-3572-7600 Federal University of Tocantins, Brazil E-mail: rubsonif@gmail.com

Marcos Odilon Dias Rodrigues ORCID: https://orcid.org/0000-0002-0216-2690 Federal University of Northern Tocantins, Brazil E-mail: marcosodilon22@gmail.com

\begin{abstract}
In recent years, agroforestry and silvopastoral systems have been gaining ground in rural areas, especially due to great acceptance by the population of products from locations that preserve the environment, being able to produce food and preserve the natural resources. This study aimed to evaluate the temporal variation of the chemical attributes of the soil in pasture areas managed with silvopastoral system and full sun (monoculture). The areas were evaluated in 2011, 2014 and 2017. Soil samples were collected at depths of 0-10 cm and 10-20 cm. Both systems presented reductions in the levels of organic matter over the evaluated period, reflecting the degradability of the material deposited in the soil. Nevertheless, it is worth mentioning that the silvopastoral system (SPS) was more efficient in maintaining the organic component when compared with monoculture, despite not maintaining regularity in the levels of organic matter in the soil. As for the other chemical parameters, there were also changes, especially related to phosphorus $(\mathrm{P})$ and potassium $(\mathrm{K})$. For $\mathrm{P}$, low replacement via organic material from the pasture and/or native trees in the SSP system were observed, resulting in a marked reduction over time. As for K, the presence of the nutrient was critical in both studied systems and depths, showing low replacement through litter.
\end{abstract}

Keywords: Attalea speciosa; Megathyrsus maximus; Litter; Organic matter.

\section{Resumo}

Os sistemas agroflorestais, silvipastoris, dentre outros vem ganhando espaço no meio rural, porque que nos últimos anos há maior aceitação pela população de produtos oriundos de localidades que preservam o ambiente e que conseguem produzir alimentos e manter da melhor forma possível os recursos naturais. O objetivo foi avaliar a variação temporal dos atributos químicos do solo em áreas de pastagens manejadas em sistema silvipastoril e pleno sol (monocultivo). Estas duas áreas foram avaliadas nos períodos de 2011, 2014 e 2017. As amostras de solo foram coletadas em nas profundidades de 0-10 cm e $10-20 \mathrm{~cm}$. Observou-se redução em ambos os sistemas nos teores de matéria orgânica ao longo do período avaliado, reflexo da degradabilidade do material depositado no solo, no entanto, 
vale ressaltar que o sistema silvipastoril (SSP) que apesar de não ter mantido a regularidade nos níveis de matéria orgânica no solo, o mesmo foi mais eficiente na manutenção deste composto orgânico quando comparado ao monocultivo, os demais parâmetros químicos também sofreram alterações com destaque para o fosforo e potássio, o primeiro demonstrou-se com baixa reposição via material orgânico oriundo da pastagem e/ou das árvores nativas no sistema SSP, resultando em redução acentuada ao longo do tempo, já para o potássio mostrou-se crítico em ambos os sistemas e nas duas profundidades avaliadas e baixa reposição via serapilheira.

Palavras-chave: Attalea speciosa; Megathyrsus maximus; Serapilheira; Matéria orgânica.

\section{Resumen}

Los sistemas agroforestales, silvopastoriles, entre otros, han ido ganando terreno en las zonas rurales, pues en los últimos años ha habido una mayor aceptación por parte de la población de productos de localidades que preservan el medio ambiente y que son capaces de producir alimentos y mantener los recursos naturales en las mejores condiciones. Una salida posible. El objetivo fue evaluar la variación temporal de los atributos químicos del suelo en áreas de pastoreo manejadas en sistema silvopastoril y pleno sol (monocultivo). Estas dos áreas fueron evaluadas en los períodos de 2011, 2014 y 2017. Las muestras de suelo se recolectaron a profundidades de 0-10 cm y 10-20 cm. Hubo una reducción en ambos sistemas en los niveles de materia orgánica durante el período evaluado, reflejando la degradabilidad del material depositado en el suelo, sin embargo, cabe mencionar que el sistema silvopastoril (SSP) que a pesar de no mantener regularidad en los niveles de materia orgánica en el suelo, fue más eficiente en el mantenimiento de este compuesto orgánico en comparación con el monocultivo, los demás parámetros químicos también sufrieron cambios con énfasis en fósforo y potasio, el primero se demostró con baja reposición vía materia orgánica del pasto y / o árboles nativos en el sistema SSP, resultando en una marcada reducción en el tiempo, para el potasio fue crítico en ambos sistemas y en las dos profundidades evaluadas y la baja reposición vía hojarasca.

Palabras clave: Attalea speciosa; Megathyrsus maximus; Basura; Materia orgánica.

\section{Introduction}

Production systems that allow the conservation of the environment and the production of food simultaneously have gained prominence in recent years. The search for more efficient production systems has been spread worldwide. In terms of local forage and tree components, in South America each system has its peculiarities that are specific to the region. However, there is a similarity in the search for sustainable and socioeconomic production alternatives (Cubbage et al., 2012).

It is essential that silvopastoral systems (SPS) can properly introduce the forage component in areas that are in the process of natural recovery, which are common in the humid tropics. This type of system can become a viable and appropriate alternative to the edaphoclimatic variations in the Amazon, reducing deforestation by breaking the vicious cycle observed in livestock and migratory agriculture, a very common situation in northern Brazil (Couto et al., 2017). For a better understanding of the association of native plants and pasture, it is necessary to study the soil impacts caused by this system.

The variation of chemical attributes over time is a reality in every production system. However, little is known about these changes in pasture environments with the presence of native forest. Thus, it is believed that moderate changes in the tree component produces can alter the deposition of organic material in the soil, consequently changing its chemical composition. This behavior might be related to the decomposition speed of the deposited material, reflecting the species richness in the area (Machado et al., 2015).

Under silvopastoral systems with native forest there is an initial tendency of decreases in the contents of organic matter in the soil. Nevertheless, it is known to remain superior to monoculture (Carvalho et al., 2016). For example, for cations such as calcium $(\mathrm{Ca})$, which is reduced in the first 30 months of implantation, changes are closely related to exports via plants and animals, for which a slow return to the soil is observed (Scoriza et al., 2017). However, silvopastoral systems with native forest show contents of $\mathrm{Ca}$ equivalent to those observed under native forest (Castro Neto et al., 2017.

Changes in soil acidity are more pronounced in silvopastoral systems when compared with full sun cultivation. This difference is directly related to the contents of organic material in the soil. Thus, it is observed that environments with the presence of a forest component present higher frequency of deposition of organic material from trees (branches, roots and 
leaves) and forages (mainly roots), generating a continuous flow of organic matter that is superior to monoculture systems (Oliveira et al., 2015; Eberling et al., 2008; Battisti et al., 2018).

The chemical attributes of the soil can vary according to the changes of the production environment, in which there would be better soil conditions in silvopastoral environment when compared with monoculture, mainly due to its plant diversity and greater conservation and nutrient recycling. In this sense, this study aimed to evaluate the temporal variation of the chemical attributes of the soil in silvopastoral and full sun system over seven years of exploration.

\section{Methodology}

The study was carried out in Araguaína, state of Tocantins, Brazil, at the Federal University of Tocantins ( $7^{\circ} 6^{\prime} 21^{\prime \prime S}$ and $48^{\circ} 11^{\prime} 19^{\prime \prime} \mathrm{W}$ ). The climate of the region is classified as Aw (hot and humid), with a well-defined season. The average annual precipitation is $1800 \mathrm{~mm}$ and the average annual temperature is $25{ }^{\circ} \mathrm{C}$. The soil is classified as Red Yellow Argisol (Embrapa, 2018), presenting the following granulometry: 53\% sand, $11 \%$ silt and $28 \%$ clay, being classified as sandy-clay.

The area used was part of a rotational system composed of three paddocks, one in monoculture and two in silvopastoral systems with two levels of shading, 30 and $60 \%$. For the present study, only the area with $30 \%$ was evaluated (Figure 1).

Figure 1. Monoculture (A) and silvopastoral (B) system.

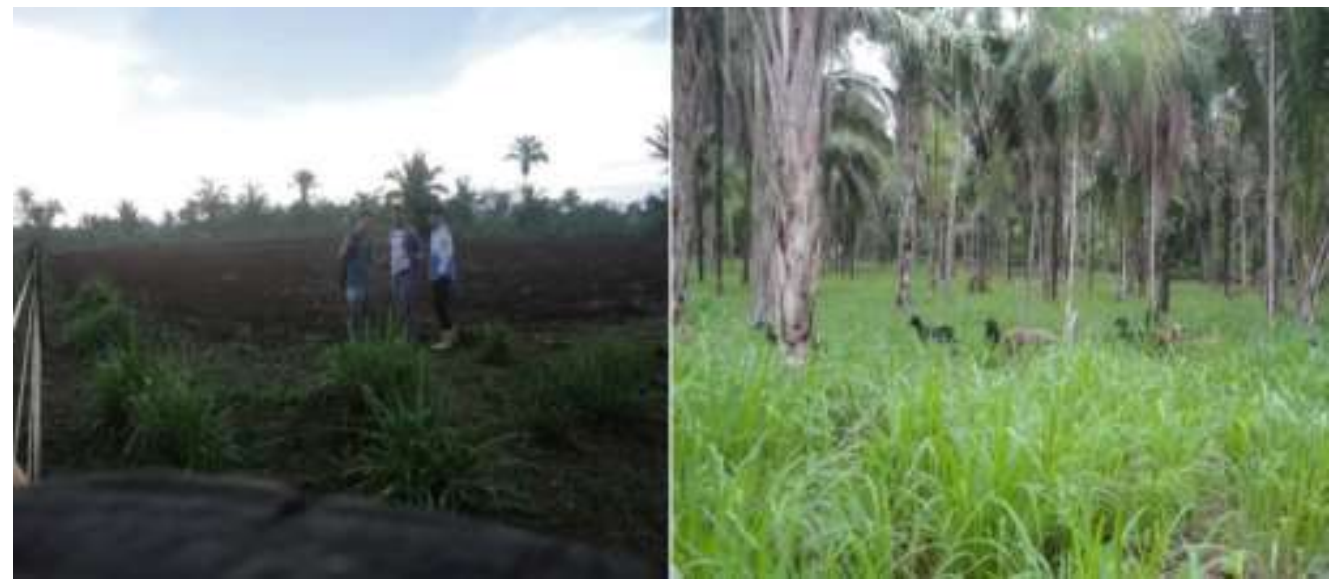

Source: Authors.

The experiment was carried out in two areas of 12,000 $\mathrm{m}^{2}$, which have been cultivated since 2011 with Megathyrsus maximus cv. Mombasa, under Silvopasture system (arboreal system with predominance of Attalea speciosa) and monoculture (Figure 1). The evaluations were carried out in 2011, 2014 and 2017, between December and March.

In 2011, chemical analysis of the soil was carried out. Before planting, phosphate fertilization was carried out with $100 \mathrm{~kg} \mathrm{ha}^{-1}$ of $\mathrm{P}_{2} \mathrm{O}_{5}$ (simple superphosphate), $120 \mathrm{~kg} \mathrm{ha}^{-1}$ of $\mathrm{K}_{2} \mathrm{O}$ (potassium chloride) and $100 \mathrm{~kg} \mathrm{ha}^{-1}$ of $\mathrm{N}$ (urea) in the period of implementation for both systems. Nitrogen was fractionated in two applications. In 2014, $60 \mathrm{~kg} \mathrm{ha}^{-1} \mathrm{P}_{2} \mathrm{O}_{5}$ (simple superphosphate), $120 \mathrm{~kg} \mathrm{ha}^{-1}$ of $\mathrm{K}_{2} \mathrm{O}$ (potassium chloride) and $150 \mathrm{~kg} \mathrm{ha}^{-1}$ of $\mathrm{N}$ (urea) were applied.

Soil samples were collected in a regular $12 \times 12 \mathrm{~m}$ sampling mesh for a better representation of the evaluated area. Thirty-six composite samples were collected, and the area was divided into nine quadrants, which were represented by four samples each, thus obtaining nine representative samples in each system. A factorial of $2 \times 3$ was formed, with two systems (monoculture and silvopastoral) and three evaluation periods (2011, 2014 and 2017). 
The collected samples were air dried, and the agglomerates were sieved at $20 \mathrm{~mm}$ and $2 \mathrm{~mm}$. The following variables were evaluated: soil organic matter $(\mathrm{OM})$ and chemical attributes: calcium $(\mathrm{Ca})$, calcium + magnesium $(\mathrm{Ca}+\mathrm{Mg})$, potassium $(\mathrm{K})$, hydrogen + aluminum $(\mathrm{H}+\mathrm{Al})$, phosphorus $(\mathrm{P})$, cation exchange capacity $(\mathrm{CEC})$, effective cation exchange capacity, sum of bases, base saturation and aluminum saturation (Embrapa, 2011).

The determination of the soil $\mathrm{pH}$ in calcium chloride $\left(\mathrm{CaCl}_{2}\right)$ and in water was carried out by the method of measuring the electro potential by means of a combined electrode immersed in soil: liquid suspension; organic matter was carried out using the wet oxidation method with potassium dichromate in a sulfuric medium, with the excess oxidation dichromate being titrated with standard ammonium ferrous sulfate solution. The ability to exchange cations and exchangeable bases were determined using $1 \mathrm{~mol} \mathrm{~L}^{-1} \mathrm{KCl}$ (Embrapa, 2011).

The data were subjected to the normality test and subsequent analysis of variance using the PROC MIXED command, adopting monoculture and silvopastoral treatments and the evaluation periods as fixed effects. The block was adopted as a random effect, using the RANDOM command. The evaluation periods and management systems were analyzed with repeated measurement over time, using the mean test via PDIFF $(\mathrm{P} \leq 0.05)$.

\section{Results and Discussion}

A significant effect was observed between the evaluated periods and $\mathrm{pH}$ in $\mathrm{CaCl}_{2}$ (Table 1) at the depth of 0-10 $\mathrm{cm}$, with values of 5.35 and 5.69 for the years 2011 and 2017, respectively. The more acidic pH in 2011 can be attributed to a higher concentration of organic matter. The soil $\mathrm{OM}$ is closely related to the increase in extractable $\mathrm{H}^{+}$and with potential acidity (Oliveira et al., 2015; Eberling et al., 2008; Battisti et al., 2018).

The $\mathrm{pH}$ in $\mathrm{CaCl}_{2}$ at the depth of 10-20 cm showed no interaction between the management systems and the evaluation periods (Table 1). However, between periods, on average, a difference of 5.34 in 2011 to 5.71 was observed in 2017. Such changes might be related to the variation in potential acidity that showed the same pattern of evolution over the observed period (Eberling et al., 2008).

In 2011 the contents of OM $(0-10 \mathrm{~cm})$ was higher when compared with 2014 and 2017, varying between 1.35 to 0.81 $\mathrm{g} \mathrm{dm}^{-3}$, respectively (Table 1). Another important detail is the participation of monoculture in the long-term reduction of organic matter, given that it decreased by $50 \%$ between 2011 and 2014, which contributed to the reduction between periods. However, in the silvopastoral system there were also reductions in OM after implantation. According to Carvalho et al. (2016), in the first months there is a great loss of organic material deposited via litter through decomposition, with a loss of up to $50 \%$ of the material in the first year, with factors such as precipitation prevailing in the degradation levels of soil OM. The integrated system is capable of retaining higher concentrations of water in the soil favoring the soil microbiota (Sousa et al., 2018; Santos, et al., 2013; Alonso, 2011).

There was variation of OM between systems $(\mathrm{P}<0.05)$ with better performance in the silvopastoral system when compared with monoculture, varying between 1.28 and $0.71 \mathrm{~g} \mathrm{dm}^{-3}$, respectively. In this way, the levels of organic matter remain higher in the integrated system. In addition to a higher initial level, SPS showed a lower rate of loss of OM from 2011 to 2014 (monoculture $=45.5 \%$ ) and (SPS $=37.8 \%$ ). These results are in agreement with Castro Neto et al. (2017) and Müller et al. (2009). According to the authors, silvopastoral systems present an annual increase of carbon in the soil varying from 1.43 to $3.71 \mathrm{Mg} \mathrm{ha}^{-1}$ year $^{-1}$ of carbon, in systems with eucalyptus and acacia, respectively, with high density of trees, which might have favored the increase of carbon, respectively.

The natural tree diversity that is another factor that may have influenced the deposition of organic material in the soil, which is a fact related to the heterogeneous pattern of material deposition between species. In this perspective, in integrated 
systems many species have a productive potential superior to monoculture with better performance, being able to sequester more organic carbon due to the better soil conditions and their interactions (Lorenz, 2014).

Table 1. Values of $\mathrm{pH}$ in calcium chloride $\left(\mathrm{pHCaCl}_{2}\right)$, Organic Matter $(\mathrm{OM})$, Aluminum $\left(\mathrm{Al}^{3+}\right)$ and Hydrogen + Aluminum $(\mathrm{H}$ $+\mathrm{Al}^{3+}$ ) for monoculture and silvopastoral systems with native forest at the depths of 0-10 and 10-20 cm.

\begin{tabular}{|c|c|c|c|c|c|}
\hline \multirow{2}{*}{ System } & \multicolumn{3}{|c|}{ Year } & \multirow{2}{*}{ Average } & \multirow{2}{*}{$p$-value } \\
\hline & 2011 & 2014 & 2017 & & \\
\hline \multicolumn{6}{|c|}{$\mathrm{pH}$ in $\mathrm{CaCl}_{2}(0-10 \mathrm{~cm})$} \\
\hline Monoculture & 5.54 & 5.41 & 5.66 & 5.54 & Sys. 0.41 \\
\hline Silvopasture & 5.16 & 5.59 & 5.71 & 5.48 & Per. 0.01 \\
\hline Average & $5.35 \mathrm{~b}$ & $5.5 \mathrm{ab}$ & $5.69 \mathrm{a}$ & & QMe 0.13 \\
\hline \multicolumn{6}{|c|}{ pH in $\mathrm{CaCl}_{2}(10-20 \mathrm{~cm})$} \\
\hline Monoculture & 5.42 & 5.26 & 5.63 & 5.44 & Sys. 0.31 \\
\hline Silvopasture & 5.25 & 5.58 & 5.78 & 5.54 & Per. 0.05 \\
\hline Average & $5.34 \mathrm{~b}$ & $5.42 \mathrm{~b}$ & $5.71 \mathrm{a}$ & & QMe 0.09 \\
\hline \multicolumn{6}{|c|}{ Organic matter $(\mathrm{OM})\left(\mathrm{g} \mathrm{dm}^{-3}\right)(0-10 \mathrm{~cm})$} \\
\hline Monoculture & 0.99 & 0.54 & 0.61 & $0.71 \mathrm{~B}$ & Sys. 0.01 \\
\hline Silvopasture & 1.72 & 1.07 & 1.05 & $1.28 \mathrm{~A}$ & Per. 0.03 \\
\hline Average & $1.35 \mathrm{a}$ & $0.81 \mathrm{~b}$ & $0.83 \mathrm{~b}$ & & QMe 0.78 \\
\hline \multicolumn{6}{|c|}{ Organic matter $(\mathrm{OM})\left(\mathrm{g} \mathrm{dm}^{-3}\right)(10-20 \mathrm{~cm})$} \\
\hline Monoculture & 0.56 & 0.29 & 0.57 & $0.47 \mathrm{~B}$ & Sys. 0.05 \\
\hline Silvopasture & 1.03 & 0.72 & 0.52 & $0.75 \mathrm{~A}$ & Per. 0.04 \\
\hline Average & $0.79 \mathrm{a}$ & $0.50 \mathrm{a}$ & $0.55 \mathrm{a}$ & & QMe 0.14 \\
\hline \multicolumn{6}{|c|}{ Aluminum $\left(\mathrm{Al}^{3+}\right)\left(\mathrm{cmol}_{\mathrm{c}} \mathrm{dm}^{-3}\right)(0-10 \mathrm{~cm})$} \\
\hline Monoculture & 0.29 & 0.078 & 0.15 & 0.1733 & Sys. 0.31 \\
\hline Silvopasture & 0.28 & 0.065 & 0.093 & 0.474 & Per. 0.01 \\
\hline Average & $0.2867 \mathrm{a}$ & $0.072 \mathrm{~b}$ & $0.122 \mathrm{~b}$ & & QMe 0.57 \\
\hline \multicolumn{6}{|c|}{ 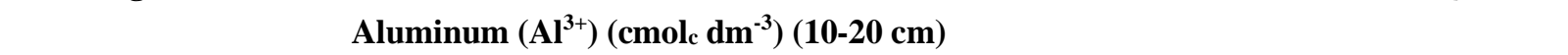 } \\
\hline Monoculture & $0.022 \mathrm{~d}$ & $0.032 \mathrm{~d}$ & $0.048 \mathrm{~d}$ & 0.034 & Sys. 0.01 \\
\hline Silvopasture & $0.317 \mathrm{a}$ & $0.081 \mathrm{c}$ & $0.110 \mathrm{~b}$ & 0.169 & Per. 0.01 \\
\hline Average & 0.170 & 0.056 & 0.079 & & QMe 0.01 \\
\hline \multicolumn{6}{|c|}{ Hydrogen + Aluminum $\left(\mathrm{H}^{+}+\mathrm{Al}^{3+}\right)\left(\mathrm{cmol}_{\mathrm{c}} \mathbf{d m}^{-3}\right)(0-10 \mathrm{~cm})$} \\
\hline Monoculture & $0.37 \mathrm{c}$ & $0.61 \mathrm{c}$ & $0.57 \mathrm{c}$ & 0.52 & Sys. 0.01 \\
\hline Silvopasture & $4.29 \mathrm{a}$ & $3.07 \mathrm{~b}$ & $2.87 \mathrm{~b}$ & 3.41 & Per. 0.01 \\
\hline Average & 2.16 & 1.56 & 1.46 & & QMe 0.01 \\
\hline \multicolumn{6}{|c|}{ Hydrogen + Aluminum $\left(\mathrm{H}^{+}+\mathrm{Al}^{3+}\right)\left(\mathrm{cmol}_{\mathrm{c}} \mathrm{dm}^{-3}\right)(10-20 \mathrm{~cm})$} \\
\hline Monoculture & $0.326 \mathrm{~d}$ & $0.068 \mathrm{e}$ & $0.083 \mathrm{e}$ & 0.15 & Sys. 0.01 \\
\hline Silvopasture & $4.55 \mathrm{a}$ & $3.09 \mathrm{~b}$ & $2.80 \mathrm{c}$ & 3.48 & Per. 0.01 \\
\hline Average & 2.44 & 1.58 & 1.44 & & QMe 0.01 \\
\hline
\end{tabular}

Averages in rows or columns followed by a different letter are statistically different by the PDIFF test $(\mathrm{P} \leq 0.05)$. QMe: mean square of the error, Sys: System, Per: Period. Source: Authors.

The soil $\mathrm{OM}$ at the depth of $10-20 \mathrm{~cm}$ was higher $(\mathrm{P}<0.05)$ in the silvopastoral system when compared with monoculture, with 0.75 and $0.47 \%$, respectively (Table 1). This difference was expected, since they are different systems with different species and different biomass volumes. Therefore, this variation is due to the concentrations of organic carbon in the soil that are higher in silvopastoral systems, essentially due to the trees that intensify the accumulation of nitrogen and carbon 
in the soil. Soil density is generally higher in open areas, which affects the storage of organic carbon in the soil (Aryal et al., 2018; Hoosbeek et al., 2016).

However, in the depth of 10-20 cm of the soil there was a decrease of this component when compared with the depth of 0-10 cm, mainly in SPS. The reduction in the carbon content in depth might be related to the lower contribution of organic content in the deeper layers when compared with the more superficial ones. Most organic matter is deposited on the soil surface by the trees, especially at 0-10 cm (Couto et al., 2017; Battisti et al., 2018; Hoosbeek et al., 2016).

The concentration of $\mathrm{OM}$ in the first $5 \mathrm{~cm}$ of the soil is related to the root system of the pasture and to the deposition of organic material from the trees. This dynamic produces micro and macro $\mathrm{OM}$, the micro coming from the pasture, with greater degradation, and the macro due to litter with a predominance of woody material of longer duration. Thus, this deposition dynamics makes the soil surface superior in organic matter (Haile et al., 2010).

The contents of aluminum in all evaluated systems and periods decreased from 0.286 to $0.072 \mathrm{cmol}_{\mathrm{c}} \mathrm{dm}^{-3}$ for 2014 in the depth of 0-10 cm (Table 1). Reductions in this attribute can be an effect of the increase in $\mathrm{pH}$, mainly in silvopastoral systems. The solubility of aluminum decreases with increasing $\mathrm{pH}$ values. However, there was also a reduction in the content of SOM in the period. Iwata et al. (2012) related this behavior to the function of OM to complex the free $\mathrm{H}^{+}$and $\mathrm{Al}^{3+}$ cations with anionic organic compounds, changing their activity in the soil profile (Iwata et al., 2012).

At the depth of $10-20 \mathrm{~cm}$ aluminum $\left(\mathrm{Al}^{3+}\right)$ showed a difference $(\mathrm{P}<0.05)$ between the systems (Table 1$)$ in all evaluated periods, with a higher concentration for silvopastoral system when compared with monoculture in the order of 0.169 and $0.034 \mathrm{cmol}_{\mathrm{c}} \mathrm{dm}^{-3}$, respectively. Despite the differences, the values are considered low for Al reduction, which might be related to $\mathrm{Al}$ being complexed with organic matter and possibly due to the cycling of $\mathrm{Ca}$ and $\mathrm{Mg}$ through the trees and animals via excretion (Arevalo et al., 1998).

The potential acidity varied $(\mathrm{P}<0.05)$ between the studied systems (Table 1$)$ at the depth of $0-10 \mathrm{~cm}$. At this depth, the behavior of SPS x MONOC was contrary over time. However, from 10-20 cm this was not verified. This could be the effect of organic matter, which decreases with depth. In SPS, the values remained between 4.29 and $2.87 \mathrm{cmol}_{\mathrm{c}} \mathrm{dm}^{-3}$, which were higher throughout the study period when compared with monoculture. In 2011, the greatest variation was observed in the order of 4.29 and $0.37 \mathrm{cmol}_{\mathrm{c}} \mathrm{dm}^{-3}$ in SPS and monoculture, respectively. This difference is related to the greater contribution of OM in SPS. The same dynamics was reported in other studies, in which relationships between greater contribution of OM and increased potential acidity were observed (Linhares et al., 2016; Eberling et al., 2008).

Regarding the contents of $\mathrm{H}+\mathrm{Al}$ at 10-20 cm deep, SPS was significantly superior to monoculture, reaching $\mathrm{H}^{+}$ contents fourteen times higher, which might be related to the percentage of organic matter in this system, which it was also superior when compared to monoculture. In the first years the high rate of degradability of organic material might have influenced the potential acidity values of the system (Table 1). Linhares et al. (2016), when studying agroforestry and conventional production systems, related the increase in soil acidity to the greater supply of organic matter in the soil produced in SPS when compared with conventional agricultural systems.

As for the contents of phosphorus (Table 2), in 2011 SPS was superior ( $<0.05$ ) when compared with monoculture, with values of 21.82 and $4.35 \mathrm{mg} \mathrm{dm}^{-3}$, respectively. In general, for P, the content it was higher in SPS and decreased over time. Nevertheless, these results were imperceptible because of the high P content in 2011 in SPS for both studied depths. In SPS there was a decrease of $85 \%$ in the concentration of P. The reduction observed from 2011 to 2014 might be related to the clay fraction in the most superficial layers. In this sense, the higher percentage of clay might have favored the adsorption of $\mathrm{P}$. Factors such as high content of clay and organic carbon are determinant for the increase in the adsorption of $\mathrm{P}$ in the soil (Valladares et al., 2003). Therefore, the clay content together with the high levels of organic material in the silvopastoral system during the first years of study might have been fundamental for the reduction of $\mathrm{P}$. 
The observed reduction was greater than that found in the literature. A reduction of $37.97 \%$ in $\mathrm{P}$ return when the system is thinned with $50 \%$ shade when compared to the native system has already been observed (Castro Neto et al., 2017). It is worth mentioning that $\mathrm{P}$ has one of the lowest returns to the soil, via litter, when compared with other macronutrients (Carvalho et al., 2016).

Table 2. Values of phosphorus $(\mathrm{P})$, calcium $\left(\mathrm{Ca}^{2+}\right)$, calcium + magnesium $(\mathrm{Ca}+\mathrm{Mg})$ and potassium $(\mathrm{K})$ for monoculture and silvopastoral system with native forest at the depths of 0-10 and $10-20 \mathrm{~cm}$.

\begin{tabular}{|c|c|c|c|c|c|}
\hline \multirow{2}{*}{ System } & \multicolumn{3}{|c|}{ Year } & \multirow{2}{*}{ Average } & \multirow{2}{*}{ p-valor } \\
\hline & 2011 & 2014 & 2017 & & \\
\hline \multicolumn{6}{|c|}{ Phosphorus $(P)\left(\mathrm{mg} \mathrm{dm}^{-3}\right)(0-10 \mathrm{~cm})$} \\
\hline Monoculture & $4.35 \mathrm{~b}$ & $3.29 \mathrm{c}$ & $3.06 \mathrm{c}$ & 3.57 & Sys. 0.01 \\
\hline Silvopasture & $21.82 \mathrm{a}$ & $3.20 \mathrm{c}$ & $3.25 \mathrm{c}$ & 9.42 & Per. 0.01 \\
\hline Average & 13.08 & 3.25 & 3.12 & & Sys*Per 0.01 \\
\hline \multicolumn{6}{|c|}{ Phosphorus $(P)\left(\mathrm{mg} \mathrm{dm}^{-3}\right)(10-20 \mathrm{~cm})$} \\
\hline Monoculture & $4.65 \mathrm{~b}$ & $3.33 \mathrm{c}$ & $3.20 \mathrm{~cd}$ & 3.73 & Sys. 0.01 \\
\hline Silvopasture & $20.29 \mathrm{a}$ & $2.82 \mathrm{e}$ & $2.90 \mathrm{ed}$ & 8.67 & Per. 0.01 \\
\hline Average & 12.47 & 3.07 & 3.05 & & Sys*Per 0.01 \\
\hline \multicolumn{6}{|c|}{ Calcium $\left(\mathrm{Ca}^{++}\right)\left(\mathrm{cmol}_{\mathrm{c}} \mathrm{dm}^{-3}\right)(0-10 \mathrm{~cm})$} \\
\hline Monoculture & 5.88 & 4.37 & 4.35 & $4.87 \mathrm{~B}$ & Sys. 0.001 \\
\hline Silvopasture & 7.88 & 6.47 & 5.92 & $6.76 \mathrm{~A}$ & Per. 0.010 \\
\hline Average & $6.88 \mathrm{a}$ & $5.42 \mathrm{~b}$ & $5.13 \mathrm{~b}$ & & QMe 0.75 \\
\hline \multicolumn{6}{|c|}{ Calcium $\left(\mathrm{Ca}^{++}\right)\left(\mathrm{cmol}_{\mathrm{c}} \mathrm{dm}^{-3}\right)(10-20 \mathrm{~cm})$} \\
\hline Monoculture & 4.59 & 3.71 & 4.10 & 4.13 & Sys. 0.10 \\
\hline Silvopasture & 5.11 & 4.38 & 4.21 & 4.57 & Per. 0.02 \\
\hline Average & $4.85^{\mathrm{a}}$ & $4.04 \mathrm{~b}$ & $4.15 b$ & & QMe 0.64 \\
\hline \multicolumn{6}{|c|}{ Calcium + Magnesium $\left(\mathrm{Ca}^{++}+\mathrm{Mg}^{++}\right)\left(\mathrm{cmol}_{\mathrm{c} . \mathrm{dm}^{-3}}\right)(0-10 \mathrm{~cm})$} \\
\hline Monoculture & 8.15 & 7.19 & 7.35 & $4.87 \mathrm{~B}$ & Sys. 0.001 \\
\hline Silvopasture & 10.4 & 9.02 & 8.92 & $6.76 \mathrm{~A}$ & Per. 0.035 \\
\hline Average & $9.28 \mathrm{a}$ & $8.11 \mathrm{~b}$ & $8.13 \mathrm{~b}$ & & QMe 0.66 \\
\hline \multicolumn{6}{|c|}{ Calcium + Magnesium $\left(\mathrm{Ca}^{++}+\mathrm{Mg}^{++}\right)\left(\mathrm{cmol}_{\mathrm{c} . \mathrm{dm}^{-3}}\right)(10-20 \mathrm{~cm})$} \\
\hline Monoculture & $20.02 \mathrm{a}$ & $6.59 \mathrm{~b}$ & $6.67 \mathrm{~b}$ & 11.09 & Sys. 0.01 \\
\hline Silvopasture & $6.77 \mathrm{~b}$ & $6.09 \mathrm{~b}$ & $6.19 \mathrm{~b}$ & 6.35 & Per. 0.01 \\
\hline Average & 13.39 & 6.34 & 6.43 & & QMe 0.01 \\
\hline \multicolumn{6}{|c|}{ Potassium $\left(\mathrm{K}^{+}\right)\left(\mathrm{mmol}_{\mathrm{c}} \mathbf{d m}^{-3}\right)(0-10 \mathrm{~cm})$} \\
\hline Monoculture & $21.37 \mathrm{a}$ & $2.70 \mathrm{c}$ & $3.15 \mathrm{~b}$ & 9.07 & Sys. 0.01 \\
\hline Silvopasture & $0.06 \mathrm{~d}$ & $0.04 \mathrm{~d}$ & $0.06 \mathrm{~d}$ & 0.06 & Per. 0.01 \\
\hline Average & 10.71 & 1.37 & 1.61 & & QMe 0.01 \\
\hline \multicolumn{6}{|c|}{ Potassium $\left(\mathrm{K}^{+}\right)\left(\mathrm{mmol}_{\mathrm{c}} \mathbf{d m}^{-3}\right)(10-20 \mathrm{~cm})$} \\
\hline Monoculture & $19.09 \mathrm{a}$ & $2.65 \mathrm{c}$ & $3.20 \mathrm{~b}$ & 3.73 & Sys. 0.01 \\
\hline Silvopasture & $0.036 \mathrm{~d}$ & $0.052 \mathrm{~d}$ & $2.90 \mathrm{~d}$ & 8.67 & Per. 0.01 \\
\hline Average & 9.56 & 3.07 & 3.05 & & QMe 0.01 \\
\hline
\end{tabular}

Averages in rows or columns followed by a different letter are statistically different by the PDIFF test $(\mathrm{P} \leq 0.05)$. QMe: mean square of the error, Sys: System, Per: Period. Source: Authors.

The reductions might also be related to the thinning of the tree system. According to Machado et al. (2015), there are lower values of this nutrient in the leaf component in more advanced tree systems due to its variation during the secondary 
succession, corroborating the hypothesis of reduction in the leaves of the P content as the succession advances. Therefore, the low return of this nutrient via litter might have influenced its low concentrations in the soil.

As for the contents of $\mathrm{P}$ at the depth of $10-20 \mathrm{~cm}$, interaction $(\mathrm{P}<0.05)$ was obtained between the systems and period over the years. In the first year (2011) the systems presented the highest values with 20.29 and $4.65 \mathrm{mg} \mathrm{dm}^{-3}$ for silvopastoral and monoculture (Table 2), respectively. Progressive reduction of $\mathrm{P}$ in the soil was obtained, mainly for the native forest $\mathrm{x}$ pasture intercropping. The explanation for this reduction is complex, but there is a cyclical trend in the increase and reduction in the concentration of $\mathrm{P}$ related to the organic-inorganic translocation and its concentration in the carbon content (Arevalo et al., 1998). In addition to the adsorption of $\mathrm{P}$ in the soil due to the percentage of clay, and the positive relationship of organic matter in the adsorption of phosphorus, it is worth mentioning that this relationship is processed through metal cation bridges ( $\mathrm{Fe}$ or $\mathrm{Al}$ ), given its anionic character, which makes the bound between organic matter and the phosphate anion viable (Bahia Filho et al., 1983).

Phosphorus has low return to the soil through natural channels such as nutrient cycling, which corroborates the study by Scoriza et al. (2017), in which the authors observed the lowest return via litter for P. It is also known that this decrease occurs in environments with reduced tree component, influenced by the lower deposition of litter (Castro Neto et al., 2017). In addition, in silvopastoral systems a higher concentration of $\mathrm{P}$ is obtained in areas of sandy soil. This corroborates the hypothesis of a reduction in $\mathrm{P}$ values due to the percentage of clay in the soil and due to the spatial variability of the nutrient, which might vary in small areas (3-5 m), with higher concentrations under trees when compared with areas far away of the row of trees (Hoosbeek et al., 2016).

Linhares et al. (2016) also observed a higher return of P in SPS when compared with monoculture. According to Battisti et al. (2018), under the canopy of trees that are more than ten years old, there is a higher content of $P$ due to the continuous deposition of organic material when compared with areas far from the canopies. The authors also pointed that up to $20 \mathrm{~cm}$ deep, the highest concentrations of this nutrient are found.

Thus, it is necessary to analyze the values for 2011 in both depths, with $21.82 \mathrm{mg} \mathrm{dm}^{-3}(0-10 \mathrm{~cm})$ and $20.2 \mathrm{mg} \mathrm{dm}^{-3}$ $(10-20 \mathrm{~cm})$ of $\mathrm{P}$, which are values higher than those verified for the other studied periods.

The content of calcium in 2014 for the silvopastoral system was higher ( $\mathrm{p}$ < 0.05). Between the studied periods, 2011 it was higher $(\mathrm{p}<0.05$ ) than 2014 and 2017, varying on average between 6.88, 5.42 and 5.13, respectively.

Maintenance of Ca values was observed between 2014 and 2017 (Table 2) due to the high return capacity of cations via recycling, which presents a slow return rate to the soil (Scoriza et al., 2017). In addition, according to Castro Neto et al. (2017), silvopastoral systems with native forest have similar Ca values when compared with native forest. It is worth noting that Ca constitutes the middle lamella of the cell wall, being considered an extremely recalcitrant structure in the plant tissue, which allows it to return to the soil more slowly (Paula et al., 2015).

The contents of $\mathrm{Ca}^{++}$at the depth of 10-20 cm showed little variation between systems and assessment periods (Table 2), with significance only for the time variance with the highest concentration in 2011 in the order of 4.85, slightly decreasing until 2014. According to Arevalo et al. (1998), the contents of $\mathrm{Ca}^{++}$show a reduction after 30 months, where the dynamics can be related to exports by fruit trees and grazing animals. These two factors (tree component and animals) might have influenced the reduction in $\mathrm{Ca}^{++}$, since the number of Babassu trees is significant and both systems were grazed by sheep from 2011 to 2017.

For the contents of $\left(\mathrm{Ca}^{++}+\mathrm{Mg}^{++}\right)$there was a marked reduction during the same period, mainly in the monoculture system, showing that $\mathrm{Mg}$ was the nutrient exported with great intensity at the beginning of the experimental period (Table 2). For Castro Neto et al. (2017), Mg has a lower return on nutrients with $\mathrm{Ca}^{++}$and P. According to the authors, the silvopastoral system with 50\% shading presented a reduction of $36 \% \mathrm{Mg}$ when compared with $80 \%$, corroborating with the present study. 
Thus, the reduction of the tree component associated with the introduction of pasture plays an important role in the contents of $\mathrm{Mg}$ in the soil.

There was a difference between the systems and periods for potassium $(\mathrm{P}<0.05)$. There was interaction between the systems with the highest concentration in 2011 for monoculture. For the other periods, the values did not follow a logical pattern, varying randomly over time.

The highest concentration in 2011 for monoculture has a direct relationship with the fertilization carried out during the period and the cultivation (harrowing and plowing), which was not possible in the silvopastoral area due to the random arrangement of the trees. Another important point is the peculiar ability of $\mathrm{K}^{+}$to move both in the soil and in the plant, so it is not uncommon to observe results, over time, that do not follow a logical concentration pattern (Battisti et al., 2018).

Table 3. Sum of bases (SB), effective cation exchange capacity (CECe) and base saturation (V\%) for monoculture and silvopastoral system with native forest at the depths of 0-10 and 10-20 cm.

\begin{tabular}{|c|c|c|c|c|c|}
\hline \multirow{2}{*}{ System } & \multicolumn{3}{|c|}{ Year } & \multirow{2}{*}{ Average } & \multirow{2}{*}{ p-valor } \\
\hline & 2011 & 2014 & 2017 & & \\
\hline \multicolumn{6}{|c|}{ Sum of Bases (SB) $\left(\mathrm{cmol}_{\mathrm{c}} \mathrm{dm}^{-3}\right)(0-10 \mathrm{~cm})$} \\
\hline Monoculture & 9.67 & 7.25 & 7.5 & $8.14 \mathrm{~B}$ & Sys. 0.04 \\
\hline Silvopasture & 10.15 & 9.07 & 8.87 & $9.36 \mathrm{~A}$ & Per. 0.01 \\
\hline Average & $9.91 \mathrm{a}$ & $8.16 \mathrm{~b}$ & $8.18 \mathrm{~b}$ & & QMe 0.59 \\
\hline \multicolumn{6}{|c|}{ Sum of Bases (SB) $\left(\mathrm{cmol}_{\mathrm{c}} \mathrm{dm}^{-3}\right)(10-20 \mathrm{~cm})$} \\
\hline Monoculture & $14.51 \mathrm{~b}$ & $6.62 \mathrm{c}$ & $6.72 \mathrm{c}$ & 9.28 & Sys. 0.01 \\
\hline Silvopasture & $20.73 \mathrm{a}$ & $6.14 \mathrm{c}$ & $6.25 \mathrm{c}$ & 11.04 & Per. 0.01 \\
\hline Average & 17.62 & 6.38 & 6.48 & & QMe 0.01 \\
\hline \multicolumn{6}{|c|}{ Effective cation exchange capacity $(\mathrm{CECe})\left(\mathrm{cmol}_{\mathrm{c}} \mathrm{dm}^{-3}\right)(0-10 \mathrm{~cm})$} \\
\hline Monoculture & 9.96 & 7.33 & 7.65 & $8.32 \mathrm{~B}$ & Sys. 0.05 \\
\hline Silvopasture & 10.48 & 9.14 & 8.96 & $9.53 \mathrm{~A}$ & Per. 0.01 \\
\hline Average & $10.22 \mathrm{a}$ & $8.23 \mathrm{~b}$ & $8.31 \mathrm{~b}$ & & QMe 0.61 \\
\hline \multicolumn{6}{|c|}{ Effective cation exchange capacity $(\mathrm{CECe})\left(\mathrm{cmol}_{\mathrm{c}} \mathrm{dm}^{-3}\right)(10-20 \mathrm{~cm})$} \\
\hline Monoculture & $14.83 \mathrm{~b}$ & $6.69 \mathrm{c}$ & $6.80 \mathrm{c}$ & 9.44 & Sys. 0.01 \\
\hline Silvopasture & $21.05 \mathrm{a}$ & $6.22 \mathrm{c}$ & $6.36 \mathrm{c}$ & 11.21 & Per. 0.01 \\
\hline Average & 17.94 & 6.45 & 6.58 & & QMe 0.01 \\
\hline \multicolumn{6}{|c|}{ Base saturation (V\%) $(0-10 \mathrm{~cm})$} \\
\hline Monoculture & 67.80 & 68.56 & 70.77 & $69.04 \mathrm{~B}$ & Sys. 0.01 \\
\hline Silvopasture & 68.93 & 74.24 & 74.90 & $72.69 \mathrm{~A}$ & Per. 0.01 \\
\hline Average & $68.36 \mathrm{~b}$ & $71.40 \mathrm{a}$ & $72.80 \mathrm{a}$ & & QMe 0.13 \\
\hline \multicolumn{6}{|c|}{ Base saturation (V\%) $(10-20 \mathrm{~cm})$} \\
\hline Monoculture & $74.17 \mathrm{~b}$ & $66.33 \mathrm{c}$ & $67.46 \mathrm{c}$ & 69.32 & Sys. 0.03 \\
\hline Silvopasture & $81.10 \mathrm{a}$ & $65.61 \mathrm{c}$ & $68.21 \mathrm{c}$ & 71.64 & Per. 0.01 \\
\hline Average & 77.63 & 65.97 & 67.84 & & QMe 0.02 \\
\hline
\end{tabular}

Averages in rows or columns followed by a different letter are statistically different by the PDIFF test $(\mathrm{P} \leq 0.05)$. QMe: mean square of the error, Sys: System, Per: Period. Source: Authors.

Potassium showed an interaction $(\mathrm{P}<0.05)$ at the depth of $10-20 \mathrm{~cm}$ in 2011 . There was a difference between the evaluated systems with 19.09 and $0.036 \mathrm{mmol}_{\mathrm{c}} \mathrm{dm}^{-3}$ of $\mathrm{K}^{+}$for the monoculture and silvopastoral, respectively. For the other periods, monoculture was slightly higher when compared to silvopastoral. This phenomenon might be related to intense tissue and fruit production. Aires et al. (2007) found critical K values in agroforestry systems, which evidences its high export rate 
via mass and fruit production, and the need for replacement, because even with the increase in the efficiency of the use of this nutrient, there is a significant reduction (Table 2).

The sharp reduction in the contents of $\mathrm{K}^{+}$between 2011 and 2014 in monoculture shows the efficiency of the root system in absolving it (Table 2). The dynamics of $\mathrm{K}^{+}$in the soil/plant system represents its efficiency in transporting itself through the root system to the plant, or even getting lost via leaching. Another factor that ought to be considered is its low replacement via litter, which can also affect its concentrations in the soil. According to Carvalho et al. (2016), similarly to $\mathrm{P}, \mathrm{K}^{+}$is the nutrient with the lowest return to soil in forests. Such factors are influenced by the locality, edaphoclimatic conditions, successional stage and species composition of the evaluated fragment (Carvalho et al., 2016).

The values of base saturation at $0-10 \mathrm{~cm}(\mathrm{~V} \%)$ (Table 3) corroborates the results observed for $\mathrm{Ca}^{++}$and $\left(\mathrm{Ca}^{++}+\mathrm{Mg}^{++}\right)$, given the positive correlation between these variables. Thus, SPS remained with the highest levels of V\% when compared with monoculture, with 72.69 and $69.04 \%$, respectively. There was a progressive increase for this variable until 2014 and maintenance of its indexes since then.

The values of base saturation at $10-20 \mathrm{~cm}$ were high for both systems and evaluated periods. The significance observed between the systems is the result of the reduction of this attribute in the silvopastoral system from 2011 to 2014, with a variation of 81.10 to $65.61 \%$, respectively.

\section{Conclusion}

The silvopastoral system was more efficient when compared with monoculture, being able to maintain higher concentrations of nutrients, such as soil organic matter, $\mathrm{Ca}^{++}$and base saturation at both evaluated depths. Thus, the integrated system is more efficient in the use and maintenance of the chemical attributes of the soil.

\section{Acknowledgments}

The authors gratefully thank the Coordination of Improvement of Higher Education Personnel (CAPES) for granting the scholarship to the first author, and the National Council of Scientific and Technological Development (CNPq).

\section{References}

Alonso, J. (2011). Silvopastoral systems and their contribution to the environmente. Cuban Jornal of Agricultural Science, 45(2), 107-113.

Arevalo, L. A., Alegre, J. C., Bandy, D. E., \& Szott, L. T. (1998). The effect of cattle grazing on soil physical and chemical properties in a silvopastoral system in the Peruvian Amazon. Agroforestry Sistems, 40, 109-124. https://doi.org/10.1023/A:1006075114659

Aryal, D. R., González, R. R. G., Nuriasmú, R. H., \& Ruiz, D. E. M. (2016). Carbon stocks and tree diversity scattered tree silvopastoral systems in Chiapas, Mexico. Agroforest systems, 93(1) 213-227. https://doi.org/10.1007/s10457-018-0310-y

Bahia Filho, A. F. C., Braga, J. M., Resende, M., \& Ribeiro, A. C. (1983). Relação entre adsorção de fosforo e componentes mineralógicos da gração argila de latossolos do planalto central. Revista Brasileira Ciência do solo, 7, 221-226.

Battisti, L. F. Z., Schmitt Filho, A. L., Loss, A., Sirisgalli, P. A. A. (2018). Soil chemical attributes in a high biodiversity silvopastoral system. Acta Agronomic, 67(4), 486-493. http://dx.doi.org/10.15446/acag.v67n4.70180.

Carvalho, D. C., Pereira, M. G., Toledo, L. O., Simon, C. A., Rodrigues, J. S., Fernandes, J. C. F., \& Castro Neto, E. C. S. (2016). Ciclagem de nutrientes de um plantio de eucalipto em regeneração de espécies nativas no sub-bosque. Floresta, 47 (1), 17-27. https://doi.org/10.5380/rf.v47i1.43652

Castro Neto, F. C., Jacovine, L. A. G., Torres, C. M. M. E., Castro Neto, S. N. O., Castro, M. M., Villanova, P. H., \& Ferreira, G. L. (2017). Balanço de Carbono-viabilidade econômica de dois sistemas Agroflorestais em Viçosa, MG. Floresta e ambiente, 24, 1-9. https://doi.org/10.1590/2179-8087.092114

Couto, W. H., Cunha dos Anjos, L. H., Pereira, M. G., Guareschi, R. F., Assunção, A. S., \& Wadt, P. G. S. (2017). Carbono, nitrogênio, abundância natural de ${ }^{13} \mathrm{C}$ e ${ }^{15} \mathrm{~N}$ do Solo sob sistemas agroflorestais. Floresta e ambiente, 24. https://doi.org/10.1590/2179-8087.009215

Cubbage, F, Balmelli, G, BussonI, A, Noellemeyer, E, Pachas, AN, Fassola, H, Colcombet, L, Rossner, B, Frey, G., Dube, F, de Silva, M. L., Stevenson, H, Hamilton, J., \& Hubbard, W. (2012). Comparing silvopastoral systems and prospects in eight regions of the world. Agroforest Systems, 86, 303-314. https://doi.org/10.1007/s10457-012-9482-z 
Eberling, A. G., Dos Anjos, L. H. C., Perez, D. V., Pereira, M. G., \& Valladares, G. S. (2008). Relação entre acidez e outros atributos químicos em solos com teores elevados de matéria orgânica. Bragantia, 67(2), 429-439.

Embrapa (2011). Manual de métodos de análise de solos / organizadores, Guilherme Kangussú Donagema.... Embrapa Solos, 230 p. - (Documentos / Embrapa Solos)

Embrapa (2018). Sistema brasileiro de classificação de solos / organizadores, Santos, H. G. dos, Jacomine, P. K. T., Anjos, L. H. C. dos, Oliveira, V. A. de, Lumbreras, J. F., Coelho, M. R., Almeida, J. A. de, Araujo Filho, J. C. de, Oliveira, J. B. de, Cunha, T. J. F.- dados eletrônicos -, Rio de Janeiro:. Embrapa solos, 237 p. (Documentos/Embrapa solos, ISBN 978-85-7035-817-2).

Haile, S. G., Nair, V D, \& Nair, P. K. R. (2010). Contribution of trees to carbon storage in soils of silvipastoral sýstems in Florida, USA. Global Change Biology, 16, 427-438. https://doi.org/10.1111/j.1365-2486.2009.01981.x

Hoosbeek, M. R., Remme, R P., \& Rusch, G. M. (2016). Trees enhance soil carbon sequestration and nutrient cycling in a silvopastoral system in southwesters Nicaragua. Agroforest Systems, 92(2), 263-273. https://doi.org/10.1007/s10457-016-0049-2

Iwata, B. F., Leite, L. F. C., Araujo, A. S. F. A., Nunes, L. A. P. L., Gehring, C., \& Campos, L. P. (2012). Sistemas agroflorestais e seus efeitos sobre os atributos quimicos em Argissolo Vermelho-Amarelo do Cerrado piauiense. Revista Brasileira de Engenharia Agrícola e Ambiental, v. 16(7), p. 731-738. https://doi.org/10.1590/S1415-43662012000700005.

Linhares, J. M. S., Bastos, W. R., Junior, R. F. S., \& OliveirA, L. C. S (2016). Variabilidade de atributos físico-químicos e dos estoques de carbono orgânico em argussolo vermelho sob sistemas agroflorestais no assentamento umari sul do amazonas. Revista Geografia Acadêmica, v.10(1), p.93-117.

Lorenz, K \& Lal, R (2014). Soil organic carbon sequestration in agroforestry systems. A review. Agronomy for Sustainable Development, 34 (2), $443-454$. https://doi.org/10.1007/s13593-014-0212-y

Machado, D. L., Pereira, M. G., Correia, M. E. F., Diniz, A. R., Santos, L. L., \& menezes, E. G. (2015). Ciclagem de nutrientes em diferentes estágios sucessionais da mata atlântica na vacia do rio paraíba no sul, RJ. Bioscience journal, 31, 1222-1237. https://doi.org/10.14393/BJ-v31n1a2015-23092

Müller, M. D., Fernandes, E. M., Castro, C. R. T., \& Paciullo, D. S. C. (2009) ALVES, FF. Estimativa de acúmulo de biomassa e carbono em sistema agrossilvipastoril na Zona da Mata Mineira. Pesquisa Florestal Brasileira, 60, 11-17.

Oliveira, I. A., Campos, M. C. C., Freitas, L., \& Soares, M. D. R. (2015). Caracterização de solos sob diferentes usos na região sul do Amazonas. Acta Amazônica, 45(1), 1-12. https://doi.org/10.1590/1809-4392201400555.

Paula, P. D., Campello, E. F. C., Guerra, J. G.M., Santos, G. A., \& Resende, A. S. (2015). Decomposição das podas das leguminosas arbóreas Gliceridia sepium E Acácia angustíssima em um sistema agroflorestal. Ciência Florestal, 25(3), 791-800. https://doi.org/10.5902/1980509819696.

Santos, D. C., Farias, M. O., Lima, C. L. R., Kunde, R. J., Pillon, C. N., \& Flores, C. A. (2013). Fracionamento químico e físico da matéria orgânica de um argissolo vermelho sob diferentes sistemas de uso. Ciência Rural, 43(5), 838-844. https://doi.org/10.1590/S0103-84782013005000037.

Scoriza, R. N., Correia, M. E. F., \& Silva, E. M. R. (2017). O estoque de serapilheira é diferente como indicador ambiental em fragmentos florestais de encosta. Revista Brasileira de Ciências Agrárias, 12 (1), 79-85. https://doi.org/10.5039/agraria.v12i1a5418

Sousa, I. R. L., Pauletto, D., Lopes, L. S. S., \& Rode, R. (2018). Decomposição de espécies utilizadas como adubação verde em sistema agroflerestal experimental, Santarém, Pará. Agroecossistemas, 10(2), 50-63. https://doi.org/10.18542/ragros.v10i2.5202

Valladares, G. S., Batistella, M., \& Pereira, M. G. (2011). Alterações ocorridas pelo manejo em latossolo, Rondônia, Amazônia Brasileira. Bragantia, 70(3), 631-637.

Valladares, G. S., Pereira, M. G., \& Anjos, L. H. (2003). Adsorção de fósforo em solos de argila de atividade baixa. Bragantia, 62(1), 111-118. 